\title{
Omalizumab for Chronic Urticaria: A Case Series and Overview of the Literature
}

\author{
Ilya Ivyanskiy Carsten Sand Simon Francis Thomsen \\ Department of Dermatology, Bispebjerg Hospital, Copenhagen, Denmark
}

\section{Key Words}

Omalizumab $\cdot$ Anti-IgE $\cdot$ Chronic urticaria $\cdot$ Biologics

\begin{abstract}
Omalizumab is a recombinant humanized monoclonal antibody that blocks the high-affinity Fc receptor of IgE. Omalizumab has been approved for the treatment of moderate to severe asthma; however, there is currently more and more data showing promising results in the management also of chronic urticaria. We present a case series of 19 patients with chronic urticaria treated in a university department with omalizumab and give an overview of the existing literature comprising an additional 59 cases as well as a total of 139 patients enrolled in two randomized controlled trials comparing omalizumab with placebo. The collective evidence points to omalizumab as a safe and effective treatment option for patients with chronic urticaria who do not sufficiently respond to standard therapy as recommended by existing guidelines.
\end{abstract}

\section{Introduction}

Urticaria is a condition characterized by localized or widespread pruritic wheals that typically exist for no more than $24 \mathrm{~h}$. By definition acute urticaria lasts no longer than six weeks, whereas chronic urticaria lasts longer, often several years. Chronic urticaria can be classified into several subtypes but these may have overlapping features [1]. Chronic urticaria that has no detectable cause is termed chronic idiopathic urticaria. Autoimmune urticaria is not a well-defined term but it is generally recognized that those with autoimmune urticaria have anti-IgG antibodies against the high-affinity IgE receptor (FcERI) on mast cells and basophils or directly to IgE antibodies. These can be documented with the urticaria histamine release (HR) test. Autoimmune urticaria affects about one third of all patients with chronic urticaria [2]. 
$\mathrm{H} 1$ antihistamines are recommended as first-line therapy for chronic urticaria; leukotriene receptor antagonists are indicated as second-line therapy, whereas immunosuppressive drugs such as corticosteroids, azathioprine or cyclosporine A should be reserved for severe recalcitrant disease [3].

Omalizumab is a recombinant humanized monoclonal antibody that blocks the highaffinity Fc receptor of IgE. Omalizumab has been approved for the treatment of moderate to severe asthma. However, there is currently more and more data showing promising results in the management of patients suffering from other allergic conditions such as chronic urticaria [4]. Omalizumab is usually recommended when other systemic therapies have failed [3].

Here we present a case series of chronic urticaria patients in a university department treated with omalizumab and give an overview of the existing literature concerning omalizumab treatment of therapy-resistant chronic urticaria.

\section{Methods}

The cases reported herein were selected consecutively from the Department of Dermatology at Bispebjerg Hospital in Copenhagen. All patients were initially referred to the department with a diagnosis of urticaria and were considered eligible for this report if they began treatment with omalizumab for urticaria during the one-year period from November 2010 to October 2011. For each case, the type and duration of urticaria was recorded as well as any previous medical treatment. If available, the results of relevant serological markers including serum total IgE and the urticaria HR test were noted. A histamine release $>16.5 \%$ was regarded as positive (Reflab, Copenhagen, Denmark). All patients were treated with omalizumab at an initial dose of $150 \mathrm{mg}$ once every two weeks, which was the department's standard dosing regimen. The clinical response to treatment with omalizumab was recorded and for each patient it was possible to score the individual response to treatment as: no response, partial response, or almost complete/complete resolution of symptoms during treatment. Furthermore, the duration and any side effects of omalizumab were recorded.

The response to treatment in our case series was compared with reports from the existing English language literature retrieved from PubMed using the search terms: 'urticaria', 'omalizumab' and 'antiIgE'. Cross-references were retrieved but this did not identify additional studies. Studies published by December 2011 were included. Three non-English case reports were identified but these were not further considered.

\section{Results}

A total of 19 patients (14 females) began treatment with omalizumab during the observation period (table 1). The mean age at the time of omalizumab initiation was 36 years for females and 49 for males. The mean duration of disease at initiation of omalizumab in the sample was 21 months for females and 24 months for males (one male patient had a duration of nine years). A total of 12 patients (63\%) were classified as having chronic idiopathic urticaria, six patients (32\%) had chronic autoimmune urticaria demonstrated by a positive urticaria HR test, whereas one patient had delayed pressure urticaria.

All patients had antihistamine-resistant disease and all but two had been treated with other systemic drugs; 14 (74\%) with prednisolone, 7 (37\%) with azathioprine, cyclosporine A and/or mycophenolate mofetil, and 6 (32\%) with TNF- $\alpha$ inhibitors. 
In total, 11 patients (58\%) experienced almost complete or complete resolution of symptoms during treatment with omalizumab, whereas five (26\%) experienced partial resolution; three patients (16\%) had no benefit of the treatment and of these, one had to discontinue treatment due to side effects (nausea, headache and flu-like symptoms). However, in general, treatment was tolerated very well and only three patients (16\%) reported side effects. These three patients were all females and among the youngest in the sample $(15,19$ and 29 years of age $)$.

\section{Discussion}

The present case series included 19 patients with therapy-resistant chronic urticaria. On an initial dose of omalizumab of $150 \mathrm{mg}$ once every two weeks, a total of $84 \%$ of the patients experienced resolution of symptoms to a degree that exceeded the effect of previous treatments. The symptomatic effect of the treatment occurred in many of the patients after one or just a few days and no serious side effects were reported.

These data add to the growing body of evidence supporting the use of omalizumab as a safe and effective treatment option for chronic urticaria. Particularly, by December 2011, to our knowledge, a total of 59 cases of chronic urticaria treated with omalizumab have been reported in the literature comprising five cases of solar urticaria, two cases of heat urticaria, two cases of cold urticaria, three cases of delayed pressure urticaria, three cases of urticaria factitia, three cases of cholinergic urticaria, 40 cases of chronic idiopathic urticaria, and 16 cases of chronic autoimmune urticaria. Furthermore, a total of 139 patients have been enrolled in two randomized controlled trials comparing omalizumab with placebo (table 2) [5-30]. The first randomized trial was restricted to patients with IgE against thyroperoxidase; 27 patients were randomized to omalizumab and 22 to placebo [29]. The absolute mean decrease in the urticaria activity score (UAS) during the 24 weeks of treatment was 17.8 points in the experimental group and 7.9 points in the placebo group. According to the investigator's global assessment, as many as $67 \%$ of the patients in the experimental group were assessed as having achieved complete resolution of symptoms during the study compared with only $4 \%$ in the placebo group. The second trial included 90 patients with chronic idiopathic urticaria randomized to one of three different doses of omalizumab $(75,300$ or $600 \mathrm{mg})$ or to placebo [30]. The absolute mean decrease in the UAS four weeks after a single dose of omalizumab was 14.6 points in the group receiving $600 \mathrm{mg}$ omalizumab, 19.9 points in the group receiving $300 \mathrm{mg}$ omalizumab, 9.8 points in the group receiving $75 \mathrm{mg}$ omalizumab, and 6.9 points in the group receiving placebo. The mean decrease in the groups receiving 300 and $600 \mathrm{mg}$ omalizumab was statistically significantly greater than in the placebo group. A total of $28.6,36.0$, and $4.4 \%$ of the patients had complete resolution of urticaria symptoms after receiving a single dose of 600,300 and $75 \mathrm{mg}$ omalizumab, respectively. No patients in the placebo group had complete resolution of symptoms. Both randomized trials reported mild but rather frequent side effects such as diarrhoea, headache, dysmenorrhoea and upper respiratory tract infections that, however, did not differ in prevalence between the groups receiving active treatment and placebo. 
The rapid improvement of urticaria symptoms reported in almost all previous cases treated with omalizumab indicates that IgE plays an important role in chronic urticaria. However, although anti-IgE mechanisms are thought to be the principal mode of action for omalizumab, several of the published cases support a role of other mechanisms such as induction of eosinophil apoptosis, downregulation of the inflammatory cytokines IL-2, IL-4, IL-13 and TNF- $\alpha$, increase in the activity of CD4+ cells by ATP release, decrease in basophil releasability as well as a marked decrease in the expression of FceRI [18, 20, 21, 25]. These observations offer an explanation for the successful results also among patients with low levels of IgE.

The dosing of omalizumab for chronic urticaria is in many cases based on the recommendations for asthma, i.e. based on serum total IgE levels and the weight of the patient [4]. We saw a marked effect in most of our patients of treatment with $150 \mathrm{mg}$ once every two weeks. In comparison, most of the previous cases were treated with a higher dose, predominantly with an initial dose of $300 \mathrm{mg}$, which was also the dose that produced the most marked clinical response in the experimental trials [30]. On the contrary, earlier published case reports, in general, overestimated the effect of omalizumab compared with the controlled trials, and also did not report side effects or scored them as negligible or absent.

Despite an undeniable value of omalizumab for chronic urticaria, it is still not clear why the drug is effective in some patients and less so in others. Nevertheless, the collective evidence points to omalizumab as a safe and effective treatment option for patients with chronic urticaria who do not sufficiently respond to standard therapy as recommended by existing guidelines [3]. 
Table 1. Characteristics of 19 consecutive patients with urticaria treated with omalizumab

\begin{tabular}{|c|c|c|c|c|c|c|c|c|c|c|c|c|}
\hline \multicolumn{3}{|c|}{$\begin{array}{l}\text { Patient } \\
\text { characteristics }\end{array}$} & \multicolumn{6}{|c|}{ Urticaria characteristics } & \multicolumn{4}{|c|}{ Omalizumab treatment } \\
\hline No. & $\operatorname{sex}$ & age & type & $\mathrm{AO}$ & duration & HR test & IgE & previous treatment & duration & dose & effect & side effects \\
\hline 1 & M & 42 & $\mathrm{CIU}$ & yes & $2 \mathrm{~m}$ & negative & & H1, Pred & $2 \mathrm{~m}$ & $150 \mathrm{mg} / 2 \mathrm{w}$ & $\uparrow \uparrow$ & none \\
\hline 2 & $\mathrm{~F}$ & 30 & CIU & yes & $2 \mathrm{~m}$ & negative & & H1, Pred & $4 \mathrm{~m}$ & $150 \mathrm{mg} / 2 \mathrm{w}$ & $\uparrow \uparrow$ & none \\
\hline 3 & $\mathrm{~F}$ & 46 & DPU & no & $3 y$ & negative & 98 & H1, Aza, CsA, TNF- $\alpha$ & $12 \mathrm{~m}$ & $150 \mathrm{mg} / 2 \mathrm{w}$ & $\uparrow$ & none \\
\hline 4 & $\mathrm{~F}$ & 29 & CAU & yes & $6 \mathrm{~m}$ & positive & & H1, Pred & $1 \mathrm{~m}$ & $150 \mathrm{mg} / 2 \mathrm{w}$ & $\rightarrow$ & none \\
\hline 5 & $\mathrm{M}$ & 66 & CIU & no & $5 \mathrm{~m}$ & negative & & $\mathrm{H} 1$ & $6 \mathrm{~m}$ & $150 \mathrm{mg} / 2 \mathrm{w}$ & $\uparrow \uparrow$ & none \\
\hline 6 & $\mathrm{~F}$ & 51 & $\mathrm{CAU}$ & no & $2 \mathrm{~m}$ & positive & & H1, Pred & $7 \mathrm{~m}$ & $150 \mathrm{mg} / 2 \mathrm{w}$ & $\uparrow \uparrow$ & none \\
\hline 7 & $\mathrm{~F}$ & 19 & CIU & yes & $2 \mathrm{~m}$ & negative & & H1, Pred & $1 \mathrm{~m}$ & $150 \mathrm{mg} / 2 \mathrm{w}$ & $\rightarrow$ & nausea \\
\hline 8 & $\mathrm{M}$ & 50 & CAU & yes & $2 \mathrm{~m}$ & positive & 7 & H1, Pred & $4 \mathrm{~m}$ & $150 \mathrm{mg} / 2 \mathrm{w}$ & $\uparrow$ & none \\
\hline 9 & $\mathrm{~F}$ & 24 & $\mathrm{CIU}$ & no & $2 y$ & negative & & H1, Pred, Mont, CsA & $9 \mathrm{~m}$ & $150 \mathrm{mg} / 2 \mathrm{w}$ & $\uparrow \uparrow$ & headache \\
\hline 10 & $\mathrm{~F}$ & 29 & $\mathrm{CIU}$ & no & $3 y$ & negative & & H1 & $2 \mathrm{~m}$ & $150 \mathrm{mg} / 2 \mathrm{w}$ & $\uparrow \uparrow$ & none \\
\hline 11 & $\mathrm{~F}$ & 37 & $\mathrm{CIU}$ & no & $2 y$ & negative & 165 & H1, Pred, TNF- $\alpha$ & $7 \mathrm{~m}$ & $150 \mathrm{mg} / 2 \mathrm{w}$ & $\uparrow \uparrow$ & none \\
\hline 12 & $\mathrm{~F}$ & 46 & CIU & no & $8 \mathrm{~m}$ & negative & & H1, H2, Pred, CsA & $7 \mathrm{~m}$ & $150 \mathrm{mg} / 2 \mathrm{w}$ & $\uparrow \uparrow$ & none \\
\hline 13 & $\mathrm{M}$ & 23 & CIU & no & $6 \mathrm{~m}$ & negative & & $\mathrm{H} 1, \mathrm{H} 2$, Pred & $2 \mathrm{~m}$ & $150 \mathrm{mg} / 2 \mathrm{w}$ & $\uparrow \uparrow$ & none \\
\hline 14 & $\mathrm{M}$ & 62 & CAU & no & $9 y$ & positive & 29 & H1, CsA, TNF- $\alpha$ & $9 \mathrm{~m}$ & $150 \mathrm{mg} / 2 \mathrm{w}$ & $\uparrow \uparrow$ & none \\
\hline 15 & $\mathrm{~F}$ & 32 & $\mathrm{CIU}$ & yes & $2 y$ & negative & 159 & H1, Pred, Aza, TNF- $\alpha$ & $15 \mathrm{~m}$ & $150 \mathrm{mg} / 2 \mathrm{w}$ & $\uparrow$ & none \\
\hline 16 & $\mathrm{~F}$ & 35 & $\mathrm{CIU}$ & yes & $3 \mathrm{~m}$ & negative & & H1, Pred, CsA & $12 \mathrm{~m}$ & $150 \mathrm{mg} / 2 \mathrm{w}$ & $\uparrow$ & none \\
\hline 17 & $\mathrm{~F}$ & 47 & CIU & no & $5 \mathrm{~m}$ & negative & & H1, Pred & $2 \mathrm{~m}$ & $150 \mathrm{mg} / 2 \mathrm{w}$ & $\uparrow \uparrow$ & none \\
\hline 18 & $\mathrm{~F}$ & 62 & CAU & no & $8 y$ & positive & 105 & H1, Aza, CsA, MMF, TNF- $\alpha$ & $4 \mathrm{~m}$ & $150 \mathrm{mg} / 2 \mathrm{w}$ & $\uparrow$ & none \\
\hline$\overline{19}$ & $\mathrm{~F}$ & 15 & CAU & no & $2 y$ & positive & & H1, Pred, TNF- $\alpha$ & $2 w$ & $150 \mathrm{mg} / 2 \mathrm{w}$ & $\rightarrow$ & $\begin{array}{l}\text { nausea, } \\
\text { headache* }\end{array}$ \\
\hline
\end{tabular}

Type: $\mathrm{CIU}=$ chronic idiopathic urticaria; $\mathrm{DPU}=$ delayed pressure urticaria; $\mathrm{CAU}=$ chronic autoimmune urticaria. $\mathrm{AO}=\mathrm{Angioedema}$. Duration: time from debut of symptoms until initiation of omalizumab ( $\mathrm{m}=$ months; $\mathrm{y}=$ years). Dose: initial dose of omalizumab ( $\mathrm{w}=\mathrm{weeks}$ ). Previous treatment: $\mathrm{H} 1 / \mathrm{H} 2$ = antihistamines; Pred = prednisolone; Mont = montelukast; Aza = azathioprine; CsA = cyclosporine A; $\mathrm{MMF}=$ mycophenolate mofetil; TNF- $\alpha=$ TNF- $\alpha$ inhibitor. Effect: overall change in clinical symptoms after treatment with omalizumab; no response $(\rightarrow)$, partial $(\uparrow)$, almost complete/complete $(\uparrow \uparrow)$ resolution of symptoms. * Patient had to discontinue omalizumab due to side effects. 
Table 2. Studies of urticaria treated with omalizumab

\begin{tabular}{|c|c|c|c|c|c|c|c|c|c|c|c|c|c|}
\hline \multicolumn{2}{|c|}{ Study characteristics } & \multicolumn{8}{|c|}{ Number of patients } & \multicolumn{4}{|c|}{ Omalizumab treatment } \\
\hline 1st author & year & SU & $\mathrm{HU}$ & $\mathrm{CU}$ & DPU & UF & $\mathrm{ChU}$ & $\mathrm{CIU}$ & CAU & $\begin{array}{l}\text { ef- } \\
\text { fect }\end{array}$ & side effects & dose & comment \\
\hline \multicolumn{14}{|l|}{ Case studies } \\
\hline Boyce [5] & 2006 & & & 1 & & & & & & $\uparrow \uparrow \uparrow$ & unknown & $375 \mathrm{mg} / 2 \mathrm{w}$ & the patient was 12 years of age \\
\hline Spector [6] & 2007 & & & & & & & 2 & 1 & 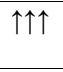 & unknown & varying & $\begin{array}{l}\text { serum total IgE was between } 9 \text { and 2,557 } \\
\mathrm{kU} / \mathrm{l}\end{array}$ \\
\hline Güzelbey [7] & 2008 & 1 & & & & & & & & $\uparrow \uparrow \uparrow$ & unknown & $150 \mathrm{mg} / 4 \mathrm{w}$ & baseline serum total IgE was $22 \mathrm{kU} / \mathrm{l}$ \\
\hline Godse [8] & 2008 & & & & & & & 1 & & $\uparrow \uparrow \uparrow$ & unknown & $300 \mathrm{mg} / 4 \mathrm{w}$ & baseline serum total IgE was $778 \mathrm{kU} / \mathrm{l}$ \\
\hline Metz [9] & 2008 & & & & & & 1 & & & $\uparrow \uparrow \uparrow$ & none & $150 \mathrm{mg} / 4 \mathrm{w}$ & complete resolution after $5 \mathrm{w}$ of treatment \\
\hline Otto [10] & 2009 & & & & & & 1 & & & $\uparrow$ & unknown & $300 \mathrm{mg} / 4 \mathrm{w}$ & $\begin{array}{l}\text { sweat collected by pilocarpine } \\
\text { iontophoresis }\end{array}$ \\
\hline Magerl [11] & 2010 & & & & 1 & & & 7 & & $\overline{\imath \uparrow}$ & few & varying & $\begin{array}{l}\text { the patient with DPU responded only } \\
\text { partially }\end{array}$ \\
\hline $\begin{array}{l}\text { Vestergaard } \\
{[12]}\end{array}$ & 2010 & & & & & & & 2 & & $\uparrow \uparrow \uparrow$ & some & varying & one patient had abdominal side effects \\
\hline Krause [13] & 2010 & & & & & 1 & & & & $\uparrow \uparrow \uparrow$ & none & $300 \mathrm{mg} / 2 \mathrm{w}$ & $\begin{array}{l}\text { symptoms recurred as drug was } \\
\text { discontinued }\end{array}$ \\
\hline Waibel [14] & 2010 & 1 & & & & & & & & $\uparrow$ & unknown & $400 \mathrm{mg} / 2 \mathrm{w}$ & $\begin{array}{l}\text { UVB action spectrum improved more than } \\
\text { UVA }\end{array}$ \\
\hline Romano [15] & 2010 & & & & & & & 2 & & $\uparrow \uparrow \uparrow$ & unknown & $400 \mathrm{mg} / 2 \mathrm{w}$ & SPT positivity maintained during treatment \\
\hline $\begin{array}{l}\text { Bullerkotte } \\
{[16]}\end{array}$ & 2010 & & 1 & & & & & & & $\uparrow \uparrow \uparrow$ & none & $450 \mathrm{mg} / 2 \mathrm{w}$ & $\begin{array}{l}\text { symptoms recurred when dose was } \\
\text { lowered }\end{array}$ \\
\hline Sabroe [17] & 2010 & & & & & & 1 & & & & none & $300 \mathrm{mg} / 2 \mathrm{w}$ & baseline serum total IgE was 1,523 kU/ml \\
\hline $\begin{array}{l}\text { Bindslev- } \\
\text { Jensen [18] }\end{array}$ & 2010 & & & & 1 & & & & & $\uparrow \uparrow \uparrow$ & none & $150 \mathrm{mg} / 2 \mathrm{w}$ & marked decrease in basophil releasability \\
\hline Al-Ahmad [19] & 2010 & & & & & & & & 3 & $\uparrow \uparrow \uparrow$ & none & $300 \mathrm{mg} / 4 \mathrm{w}$ & no symptoms $12 \mathrm{w}$ after discontinuation \\
\hline Iemoli [20] & 2010 & & & & & & & 1 & & $\uparrow \uparrow \uparrow$ & unknown & $300 \mathrm{mg} / 2 \mathrm{w}$ & $\downarrow$ in TNF- $\alpha$ and IL-4; $\uparrow$ in IFN- $\gamma$ \\
\hline Saavedra [21] & 2011 & & & & & & & 1 & & $\uparrow \uparrow$ & none & $300 \mathrm{mg} / 2 \mathrm{w}$ & $80 \%$ decrease in the expression of FceRI \\
\hline Groffik [22] & 2011 & & & & & & & 9 & & $\uparrow \uparrow$ & few & varying & effect is the average across all patients \\
\hline Metz [23] & 2011 & 2 & 1 & 1 & 1 & 2 & & & & $\uparrow \uparrow$ & none & varying & five of seven patients responded completely \\
\hline Godse [24] & 2011 & & & & & & & 5 & & $\uparrow \uparrow$ & few & $300 \mathrm{mg} / 2-4$ & $v$ the urticaria activity score (UAS) was used \\
\hline $\begin{array}{l}\text { Sánchez- } \\
\text { Machín [25] }\end{array}$ & 2011 & & & & & & & 1 & & $\uparrow \uparrow \uparrow$ & none & $300 \mathrm{mg} / 2 \mathrm{w}$ & increase in activity of CD4+ by ATP release \\
\hline Duchini [26] & 2011 & 1 & & & & & & & & $\rightarrow$ & unknown & $150 \mathrm{mg} / 4 \mathrm{w}$ & $\begin{array}{l}\text { reactive to UVA and visible light but not } \\
\text { UVB }\end{array}$ \\
\hline \multicolumn{14}{|c|}{ Observational studies } \\
\hline Kaplan [27] & 2008 & & & & & & & & 12 & $\uparrow \uparrow$ & none & varying & $\begin{array}{l}\text { one patient was a nonresponder to } \\
\text { treatment }\end{array}$ \\
\hline Ferrer [28] & 2011 & & & & & & & 9 & & $\uparrow \uparrow$ & unknown & $300 \mathrm{mg}$ & basophil counts did not change significantly \\
\hline \multicolumn{14}{|c|}{ Controlled trials } \\
\hline \multirow[t]{3}{*}{ Maurer [29] } & 2011 & & & & & & & & & & & & patients had IgE against thyroperoxidase \\
\hline & & & & & & & & 27 & & $\uparrow \uparrow$ & in $81.5 \%$ & varying & UAS decreased 17.8 points during treatment \\
\hline & & & & & & & & 22 & & $\uparrow$ & in $86.4 \%$ & placebo & UAS decreased 5.8 points during treatment \\
\hline \multirow[t]{5}{*}{ Saini [30] } & 2011 & & & & & & & & & & & & $75 \mathrm{mg}$ omalizumab not better than placebo \\
\hline & & & & & & & & 21 & & $\uparrow \uparrow$ & in $47.6 \%$ & $600 \mathrm{mg}$ & UAS decreased 14.6 points during treatment \\
\hline & & & & & & & & 25 & & $\uparrow \uparrow$ & in $48.0 \%$ & $300 \mathrm{mg}$ & UAS decreased 19.9 points during treatment \\
\hline & & & & & & & & 23 & & & in $34.8 \%$ & $75 \mathrm{mg}$ & UAS decreased 9.8 points during treatment \\
\hline & & & & & & & & 21 & & $\uparrow$ & in $47.6 \%$ & placebo & UAS decreased 6.9 points during treatment \\
\hline
\end{tabular}

$\mathrm{SU}=$ Solar urticaria; $\mathrm{HU}=$ heat urticaria; $\mathrm{CU}=$ cold urticaria; DPU = delayed pressure urticaria; $\mathrm{UF}=$ urticaria factitia; $\mathrm{ChU}=\mathrm{cholinergic}$ urticaria; $\mathrm{CIU}=$ chronic idiopathic urticaria; $\mathrm{CAU}=$ chronic autoimmune urticaria. Effect is overall change in clinical symptoms after treatment with omalizumab; no response $(\rightarrow)$, partial $(\uparrow)$, almost complete $(\uparrow \uparrow)$ or complete $(\uparrow \uparrow \uparrow)$ resolution of symptoms. $w=$ Weeks. 


\section{References}

1 Zuberbier T, Asero R, Bindslev-Jensen C, Walter Canonica G, Church MK, Giménez-Arnau A, Grattan CE, Kapp A, Merk HF, Rogala B, Saini S, Sánchez-Borges M, Schmid-Grendelmeier P, Schünemann H, Staubach P, Vena GA, Wedi B, Maurer M; Dermatology Section of the European Academy of Allergology and Clinical Immunology; Global Allergy and Asthma European Network; European Dermatology Forum; World Allergy Organization: EAACI/GA(2)LEN/EDF/WAO guideline: definition, classification and diagnosis of urticaria. Allergy 2009;64:1417-1426.

-2 Brunetti L, Francavilla R, Miniello VL, Platzer MH, Rizzi D, Lospalluti ML, Poulsen LK, Armenio L, Skov PS: High prevalence of autoimmune urticaria in children with chronic urticaria. J Allergy Clin Immunol 2004;114:922-927.

-3 Zuberbier T, Asero R, Bindslev-Jensen C, Walter Canonica G, Church MK, Giménez-Arnau AM, Grattan CE, Kapp A, Maurer M, Merk HF, Rogala B, Saini S, Sánchez-Borges M, Schmid-Grendelmeier P, Schünemann H, Staubach P, Vena GA, Wedi B; Dermatology Section of the European Academy of Allergology and Clinical Immunology; Global Allergy and Asthma European Network; European Dermatology Forum; World Allergy Organization: EAACI/GA(2)LEN/EDF/WAO guideline: management of urticaria. Allergy 2009;64:1427-1443.

4 Vichyanond P: Omalizumab in allergic diseases, a recent review. Asian Pac J Allergy Immunol 2011;29:209-219.

5 Boyce JA: Successful treatment of cold-induced urticaria/anaphylaxis with anti-IgE. J Allergy Clin Immunol 2006;117:1415-1418.

-6 Spector SL, Tan RA: Effect of omalizumab on patients with chronic urticaria. Ann Allergy Asthma Immunol 2007;99:190-193.

7 Güzelbey 0, Ardelean E, Magerl M, Zuberbier T, Maurer M, Metz M: Successful treatment of solar urticaria with anti-immunoglobulin E therapy. Allergy 2008;63:1563-1565.

$>8$ Godse KV: Omalizumab in severe chronic urticaria. Indian J Dermatol Venereol Leprol 2008;74:157-158.

$\checkmark 9$ Metz M, Bergmann P, Zuberbier T, Maurer M: Successful treatment of cholinergic urticaria with antiimmunoglobulin E therapy. Allergy 2008;63:247-249.

10 Otto HF, Calabria CW: A case of severe refractory chronic urticaria: a novel method for evaluation and treatment. Allergy Asthma Proc 2009;30:333-337.

-11 Magerl M, Staubach P, Altrichter S, Ardelean E, Krause K, Metz M, Weller K, Maurer M: Effective treatment of therapy-resistant chronic spontaneous urticaria with omalizumab. J Allergy Clin Immunol 2010;126:665-666.

12 Vestergaard C, Deleuran M: Two cases of severe refractory chronic idiopathic urticaria treated with omalizumab. Acta Derm Venereol 2010;90:443-444.

13 Krause K, Ardelean E, Kessler B, Magerl M, Metz M, Siebenhaar F, Weller K, Worm M, Zuberbier T, Maurer M: Antihistamine-resistant urticaria factitia successfully treated with anti-immunoglobulin $\mathrm{E}$ therapy. Allergy 2010;65:1494-1495.

14 Waibel KH, Reese DA, Hamilton RG, Devillez RL: Partial improvement of solar urticaria after omalizumab. J Allergy Clin Immunol 2010;125:490-491.

15 Romano C, Sellitto A, De Fanis U, Esposito G, Arbo P, Giunta R, Lucivero G: Maintenance of remission with low-dose omalizumab in long-lasting, refractory chronic urticaria. Ann Allergy Asthma Immunol 2010;104:95-97.

16 Bullerkotte U, Wieczorek D, Kapp A, Wedi B: Effective treatment of refractory severe heat urticaria with omalizumab. Allergy 2010;65:931-932.

17 Sabroe RA: Failure of omalizumab in cholinergic urticaria. Clin Exp Dermatol 2010;35:e127-e129.

18 Bindslev-Jensen C, Skov PS: Efficacy of omalizumab in delayed pressure urticaria: a case report. Allergy 2010;65:138-139.

19 Al-Ahmad M: Omalizumab therapy in three patients with chronic autoimmune urticaria. Ann Saudi Me 2010;30:478-481.

20 Iemoli E, Piconi S, Fusi A, Borgonovo L, Borelli M, Trabattoni D: Immunological effects of omalizumab in chronic urticaria: a case report. J Investig Allergol Clin Immunol 2010;20:252-254.

-21 Saavedra MC, Sur S: Down regulation of the high-affinity IgE receptor associated with successful treatment of chronic idiopathic urticaria with omalizumab. Clin Mol Allergy 2011;9:2.

-22 Groffik A, Mitzel-Kaoukhov H, Magerl M, Maurer M, Staubach P: Omalizumab - an effective and safe treatment of therapy-resistant chronic spontaneous urticaria. Allergy 2011;66:303-305. 
23 Metz M, Altrichter S, Ardelean E, Kessler B, Krause K, Magerl M, Siebenhaar F, Weller K, Zuberbier T, Maurer M: Anti-immunoglobulin E treatment of patients with recalcitrant physical urticaria. Int Arch Allergy Immunol 2011;154:177-180.

24 Godse KV: Omalizumab in treatment-resistant chronic spontaneous urticaria. Indian J Dermatol 2011;56:444

25 Sánchez-Machín I, Iglesias-Souto J, Franco A, Barrios Y, Gonzalez R, Matheu V: T cell activity in successful treatment of chronic urticaria with omalizumab. Clin Mol Allergy 2011;9:11.

26 Duchini G, Bäumler W, Bircher AJ, Scherer K: Failure of omalizumab (Xolair ${ }^{\circledast}$ ) in the treatment of a case of solar urticaria caused by ultraviolet A and visible light. Photodermatol Photoimmunol Photomed 2011;27:336-337.

27 Kaplan AP, Joseph K, Maykut RJ, Geba GP, Zeldin RK: Treatment of chronic autoimmune urticaria with omalizumab. J Allergy Clin Immunol 2008;122:569-573.

28 Ferrer M, Gamboa P, Sanz ML, Goikoetxea MJ, Cabrera-Freitag P, Javaloyes G, Berroa F, Kaplan AP: Omalizumab is effective in nonautoimmune urticaria. J Allergy Clin Immunol 2011;127:1300-1302.

29 Maurer M, Altrichter S, Bieber T, Biedermann T, Bräutigam M, Seyfried S, Brehler R, Grabbe J, Hunzelmann N, Jakob T, Jung A, Kleine-Tebbe J, Mempel M, Meurer M, Reich K, Ruëff F, Schäkel K, Sengupta K, Sieder C, Simon JC, Wedi B, Zuberbier T, Mahler V, Staubach P: Efficacy and safety of omalizumab in patients with chronic urticaria who exhibit IgE against thyroperoxidase. J Allergy Clin Immunol 2011;128:202-209.e5.

30 Saini S, Rosen KE, Hsieh HJ, Wong DA, Conner E, Kaplan A, Spector S, Maurer M: A randomized, placebocontrolled, dose-ranging study of single-dose omalizumab in patients with H1-antihistamine-refractory chronic idiopathic urticaria. J Allergy Clin Immunol 2011;128:567-573.e1. 